\title{
Aplikasi Pembelajaran Proses Pembuatan Babi Guling dengan Objek 3D Berbasis Android
}

\author{
Agus Ghana Putra Partama Yasa, Oka Sudana, Sutramiani \\ Program Studi Teknologi Informasi, Fakultas Teknik, Universitas Udayana \\ Bukit Jimbaran, Bali, Indonesia, telp. (0361) 701806 \\ e-mail: ghanaagus@gmail.com, agungokas@unud.ac.id, sutramiani@unud.ac.id
}

\begin{abstract}
Abstrak
Babi guling merupakan makanan tradisional yang berasal dari Indonesia yang memiliki rasa yang sangat unik. Proses pembuatan babi guling umumnya hanya disajikan dalam bentuk informasi atau gambar dua dimensi yang dimuat dalam platform website ataupun buku resep makanan, yang membuat keterbatasan informasi untuk dipelajari. Masalah keterbatasan informasi dan kurang efektifnya penyampaian mengenai proses pembuatan babi guling dapat diatasi dengan memvisualisasikan informasi mengenai proses pembuatan babi guling. Aplikasi Pembelajaran Proses Pembuatan Babi Guling dengan Objek 3D Berbasis Android merupakan aplikasi proses pembuatan babi guling yang menyediakan beragam informasi mengenai alat, bahan bumbu dan proses pengolahan babi guling. Aplikasi Pengolahan Babi Guling dikembangkan dengan berbasis Android menggunakan objek 3D sehingga terkesan nyata seperti aslinya. Hasil pengujian pada empat perangkat Android memberikan hasil bahwa Aplikasi Pengolahan Babi Guling memerlukan minimal RAM 1.5 GB. Hasil kuesioner dari 30 responden yaitu respon yang baik sebagai media pembelajaran dalam mempelajari proses pembuatan babi guling, dengan persentase $90 \%$ sangat baik dalam aspek user interface, $63 \%$ baik dalam aspek rekayasa perangkat lunak, 80\% sangat baik dalam aspek edukasi, dan $83 \%$ dalam aspek overall aplikasi.
\end{abstract}

Kata kunci: Makanan tradisional, Babi Guling, Android, Media Pembelajaran

\begin{abstract}
Suckling Pig is a traditional food originating from Indonesia that has a very unique taste. The process of making Suckling Pig is generally only presented in the form of information or two-dimensional images that are loaded on the website platform or food recipe books, which make it less desirable to learn. This problem can be overcome by visualizing information about the process of making pork rolls. Learning Applications The Process of Making Suckling Pig with 3D Objects Based on Android is an application for processing suckling pig that provides a variety of information about tools, seasoning ingredients and processing of suckling pig made in the form of $3 D$ objects so as to make a real impression like the original. The application of Suckling Pig Processing is expected to help preserve traditional food, especially suckling pig through instructional media. The test results on four Android devices gave the results that the Suckling Pig Processing Application requires a minimum of 1.5 GB RAM. The questionnaire results received a good response and conducted by 30 respondents as aids in learning the process of making suckling pig, with a percentage of $90 \%$ excellent in aspects of the user interface, $63 \%$ in aspects of software engineering, $80 \%$ very good in aspects of education, and $83 \%$ in the aspect of overall applications.
\end{abstract}

Keywords: Traditional food, Suckling Pig, Android, Instructional Media.

\section{Pendahuluan}

Indonesia merupakan negara kepulauan yang memiliki berbagai kebudayaan. Salah satunya adalah makanan tradisional. Makanan tradisional merupakan salah satu peninggalan karya seni dan teknologi nenek moyang yang perlu untuk dikenal, dilestarikan dan dikembangkan agar budaya daerah tidak lenyap karena masuknya budaya asing. Salah satu makanan tradisional khas Bali adalah Babi Guling. Babi Guling merupakan sejenis makanan 
yang terbuat dari babi yang perutnya berisi bumbu rempah-rempah dan dipanggang dengan cara diputar atau digulingkan hingga ditandai dengan perubahan warna kulit menjadi kecoklatan dan renyah [1]. Proses pembuatan babi guling umumnya hanya disajikan dalam bentuk informasi atau gambar dua dimensi yang dimuat dalam platform website ataupun buku resep makanan, yang membuat keterbatasan informasi untuk dipelajari. Masalah keterbatasan informasi dan kurang efektifnya penyampaian mengenai proses pembuatan babi guling dapat diatasi dengan memvisualisasikan dalam bentuk animasi 3D.

Animasi 2 dimensi hanya memiliki dimensi panjang $(\mathrm{X})$ dan lebar $(\mathrm{Y})$, animasi 3 dimensi selain memiliki kedua dimensi tersebut juga memiliki dimensi kedalaman (Z). Animasi 3 dimensi didefinisikan sebagai animasi yang dapat dilihat dari berbagai sudut pandang (point of view) [2]. Aplikasi berbasis Android dengan jenis media pembelajaran yang memberikan informasi mengenai proses pembuatan Babi Guling, dibuat pada penelitian ini sebagai solusi keterbatasan informasi mengenai proses pembuatan babi guling.

Penelitian sebelumnya terkait pelestarian budaya dan media pembelajaran yaitu "Aplikasi Pembelajaran Membuat Ketupat dengan Animasi Model 3D berbasis Android" oleh Wijaya [3], "Aplikasi Animasi 3 Dimensi Mendem Ari-Ari Berbasis Android" oleh Sagotri [4], "Information System of Yadnya Ceremony on Android-Based" oleh Wahyu [5], "Application of Basic Balinese Dance Using Augmented Reality on Android" oleh Franza [6], "Rancang Bangun Game Tapel Bali pada Platform Android" oleh Putra [7], "Aplikasi 3D Terrain Virtual Recreation Garuda Wisnu Kencana Cultural Park" oleh Indra [2], dan "Rancang Bangun Animasi 3D Pembelajaran Shalat Jenazah Berbasis Android" oleh Gembong [8]. Penelitian oleh Wijaya membahas mengenai proses pembuatan ketupat dengan objek 3D. Tujuan aplikasi pembelajaran pembuatan ketupat dibangun untuk mempermudah masyarakat mendapatkan informasi mengenai proses pembuatan ketupat dengan menampilkan objek 3D. Penelitian oleh Wahyu membahas mengenai sistem informasi dari upacara keagamaan Hindu yaitu Yadnya sebagai sistem informasi berbasis Android yang membahas tentang pelaksanaan upacara Yadnya, prosedur pelaksanaan, pemuput, dan tempat upacara Yadnya. Penelitian oleh Sagotri membahas mengenai proses upacara mendem ari-ari yang menampilkan objek animasi 3 dimensi, memberikan informasi melalui video nyata dari upacara proses mendem ari-ari serta menampilkan foto sarana yang digunakan dalam proses mendem ari-ari. Penelitian oleh Franza membahas mengenai augmented reality Budaya Bali yaitu Tari Bali sebagai media pembelajaran gerakan Tari Bali yang interaktif dan menarik. Penelitian oleh Putra membahas mengenai game yang merancang Topeng Bali untuk mengenalkan Budaya Bali khususnya Topeng Bali dengan menggunakan game engine CoronaSDK. Penelitian oleh Indra membahas mengenai penerapan konsep objek 3D kedalam virtual environtment yang didesain menyerupai kondisi lapangan GWK berdasarkan masterplan 2014. Perancangan aplikasi 3 dimensi terrain virtual recreation GWK menggunakan physical world bertempat pada area Garuda Wisnu Kencana Cultural Park. Tujuan dari aplikasi aplikasi 3D terrain virtual recreation GWK adalah untuk mengembangkan media 3 dimensi sebagai fitur perjalanan untuk memudahkan pengunjung mengetahui tata letak bangunan GWK dan perasaan immersive dan nyata dapat dirasakan oleh user apabila pengoperasiannya disertai dengan pengunaan head mounted display. Penelitian oleh Gembong membahas tentang pembuatan aplikasi media pembelajaran shalat jenazah berbasis android. Informasi yang diberikan pada proses shalat jenazah diawali dengan membaca niat, membaca al-fatihah, membaca shalawat, membaca doa untuk jenazah, membaca doa. Proses berwudhu diawali dengan membaca bismillah, mencuci telapak tangan sebanyak tiga kali, mengambil air dengan tangan kanan kemudian berkumurkumur, memasukkan air ke hidung dan mengeluarkannya sebanyak tiga kali, membasuh wajah tiga kali, mencuci kedua tangan sampai siku tiga kali, mengusap kepala dan kedua telinga sekali usap, serta mencuci kaki sampai mata kaki tiga kali. Aplikasi shalat jenazah bertujuan untuk memberikan informasi mengenai pembelajaran tata cara berwudhu dan shalat jenazah yang menggunakan objek animasi 3D.

Aplikasi yang dikembangkan serupa dengan penelitian sebelumnya yaitu dengan tujuan pelestarian Budaya Bali yang dikemas dalam bentuk media pembelajaran berbasis Android memanfaatkan objek 3D dengan topik berbeda yaitu pembuatan Babi Guling. Aplikasi pengolahan babi guling dibuat dengan menggunakan aplikasi Unity dengan Bahasa pemrograman $\mathrm{C \#}$ yang dijalankan pada platform Android. Pemodelan objek 3D digunakan karena dapat memudahkan pengguna paham terhadap proses pembuatan babi guling. 


\section{Metodelogi Penelitian}

Metodologi penelitian berisi tahapan atau gambaran dari penelitian. Metodologi yang digunakan dalam perancangan Aplikasi Pengolahan Babi Guling adalah pengumpulan data, perancangan aplikasi, pembuatan aplikasi dan evaluasi aplikasi. Tahap pengerjaan aplikasi dilakukan melalui beberapa tahapan atau metode yang dijabarkan dalam penelitian.

\subsection{Pengumpulan Data}

Metode pengumpulan data dengan observasi dilakukan dengan cara mengambil video pada saat proses pembuatan babi guling sedang berlangsung di daerah PadangSambian Denpasar supaya bisa dijadikan sebagai acuan untuk membuat karakter dan alur cerita saat pembuatan animasi. Metode pengumpulan data dengan wawancara mengenai proses pembuatan babi guling dilakukan dengan berbagai narasumber. Sedangkan metode kepustakaan dilakukan dengan cara mengumpulkan data dari referensi buku, penelitian sebelumnya, jurnal, e-book yang berkaitan dengan Animasi Pembelajaran.

\subsection{Perancangan Sistem}

Aplikasi Pembelajaran Proses Pembuatan Babi Guling dengan Objek 3D Berbasis Android merupakan sebuah aplikasi media pembelajaran yang digunakan untuk mempelajari makanan tradisional khususnya babi guling. Aplikasi proses pembuatan babi guling menampilkan informasi umum mengenai bahan, bumbu dan proses pembuatan babi guling dengan onjek 3D.

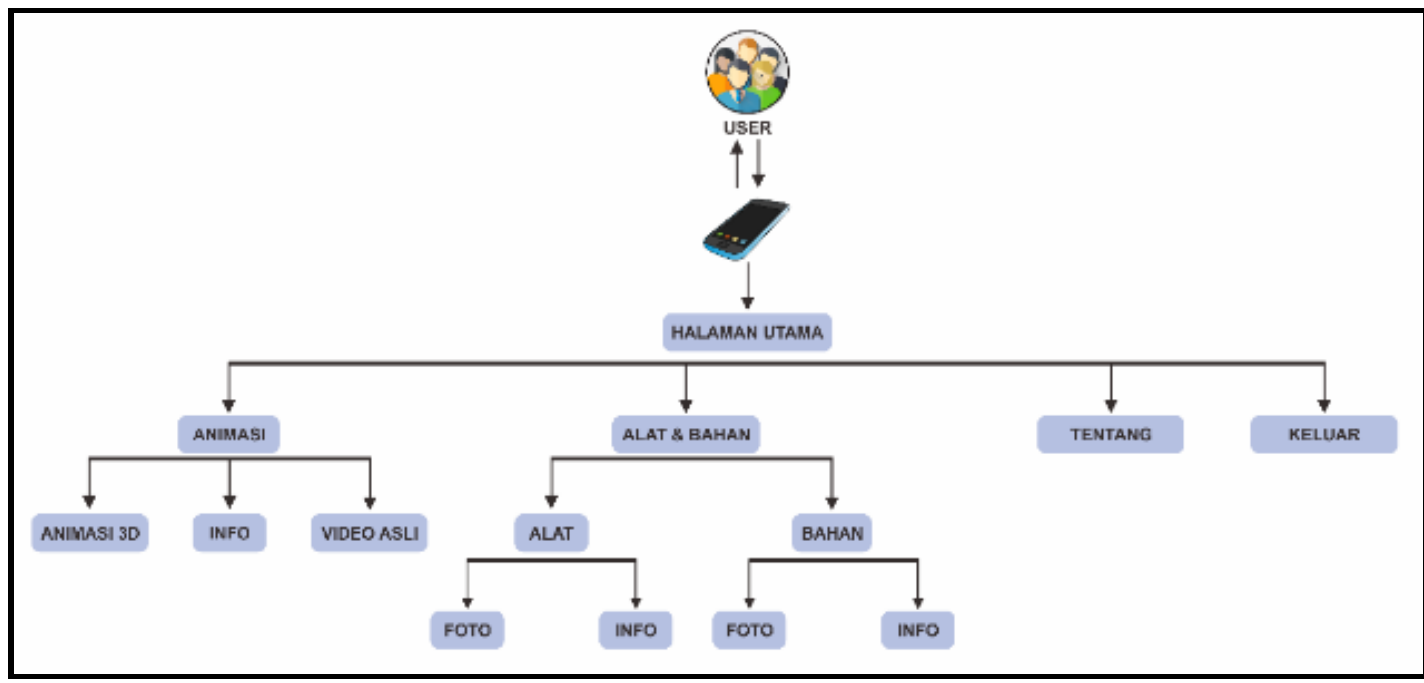

. Gambar 1. Gambaran Umum Sistem

Gambar 1 merupakan gambaran umum dari Aplikasi Pengolahan Babi Guling. Pertama user memilih pilihan pada menu utama. User dapat memilih menu animasi untuk menampilkan animasi 3D, informasi dan video nyata dari proses pengolahan Babi Guling. User dapat memilih menu alat dan bahan yang menampilkan foto serta bahan yang digunakan dalam pengolahan Babi Guling. Menu utama dari aplikasi pengolahan Babi Guling yang lain yaitu menu tentang dan keluar. Menu tentang dipilih untuk menampilkan informasi mengenai aplikasi pengolahan Babi Guling. Menu keluar dipilih untuk menghentikan aplikasi.

\section{Kajian Pustaka}

Bagian kajian pustaka memuat semua pustaka yang dijadikan acuan pada penelitian proses pembuatan Babi Guling. Sumber yang digunakan dalam penelitian diperoleh dari buku, internet, maupun jurnal diuraikan. Pustaka penunjang yang disertakan yaitu materi penunjang dan aplikasi pendukung yang digunakan dalam pembuatan aplikasi. 


\subsection{Animasi}

Animasi berasal dari kata animate yang dapat diartikan sebagai menggerakan sesuatu objek yang diam. Animasi tidak pernah berkembang tanpa ditemukannya prinsip dasar dari karakter mata manusia yaitu persistance of vision (pola penglihatan yang teratur). Perkembangan animasi bisa didefinisikan sebagai suatu sequence gambar yang diekspos pada tenggang waktu tertentu sehingga tercipta sebuah ilusi gambar bergerak [8].

\subsection{Aplikasi Pembelajaran Interaktif}

Aplikasi pembelajaran interaktif merupakan sistem yang memiliki aktivitas pemrosesan perintah yang diperlukan untuk melaksanakan permintaan pengguna dengan tujuan tertentu. Sedangkan menurut Janner aplikasi merupakan program atau sekelompok program yang dirancang untuk digunakan oleh pengguna akhir (end user). Aplikasi dapat digunakan sebagai media pemanfaatan untuk keperluan pembelajaran kepada siswa mengingat dalam proses pembelajaran seharusnya terdapat interaksi antar komponen pembelajaran. Salah satu pendekatan pembelajaran yang memungkinkan antara komponen pembelajaran adalah pembelajaran interaktif [9].

\subsection{Android}

Android merupakan salah satu sistem operasi perangkat selular yang dirancang untuk perangkat selular layar sentuh berbasis Linux. Android adalah sebuah platform open source untuk dikembangkan dengan bebas sehingga terdapat banyak aplikasi yang tidak berbayar untuk penggguna [10]. Open source memungkinkan perangkat dalam jumlah yang besar untuk menjalankan aplikasi yang sama dan menciptakan ekosistem yang jauh lebih beragam untuk para pengembang dan konsumen.

\subsection{Babi Guling}

Babi Guling adalah jenis makanan yang terbuat dari anak babi yang perutnya berisi bumbu dan sayuran seperti potongan kunyit, daun ketela pohon beserta bumbu rempah rempah lainnya. Nama lain dari Babi Guling untuk daerah Bali lebih dikenal dengan Be Guling [1]. Proses pembuatan babi guling dilakukan secara tradisioanal, dimulai dari menyembelih babi, membersihkan bulu dan kulit (epydermis), mengeluarkan organ dalam, mengikat mulut dan keempat kaki, mengisi bumbu pada perut babi, kemudian babi diguling pada bara api sambil memutar alat penggulingan sampai matang, babi yang sudah matang ditandai dengan warna cokelat kemerahan.

\section{Hasil dan Pembahasan}

\subsection{Tampilan Aplikasi Pengolahan Babi Guling}

Aplikasi pengolahan babi guling diawali dengan Tampilan Menu Utama. Pada tampilan Menu Utama disajikan empat menu pilihan, yaitu Menu Animasi, Menu Alat\&Bahan, Menu Tentang dan Menu Keluar. Tampilan awal Halaman Menu Utama ditampilkan pada Gambar 2.

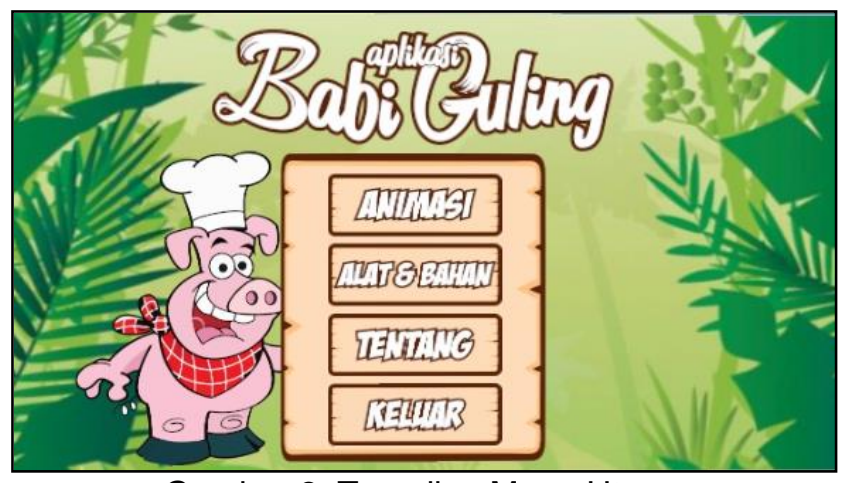

Gambar 2. Tampilan Menu Utama

Gambar 2 menampilkan Halaman Menu Utama yang memiliki pilihan menu yaitu, Animasi, Alat\&Bahan, Tentang dan Keluar. Menu Animasi berisi animasi 3D yang digunakan dalam proses pembuatan babi guling. Menu Alat\&Bahan menjelaskan tentang alat dan bahan yang digunakan pada proses pembuatan babi guling. Menu Tentang berisi keterangan tentang 
aplikasi dan yang membuat aplikasi. Menu Keluar menampilkan pilihan mengakhiri atau melanjutkan menggunakan aplikasi.

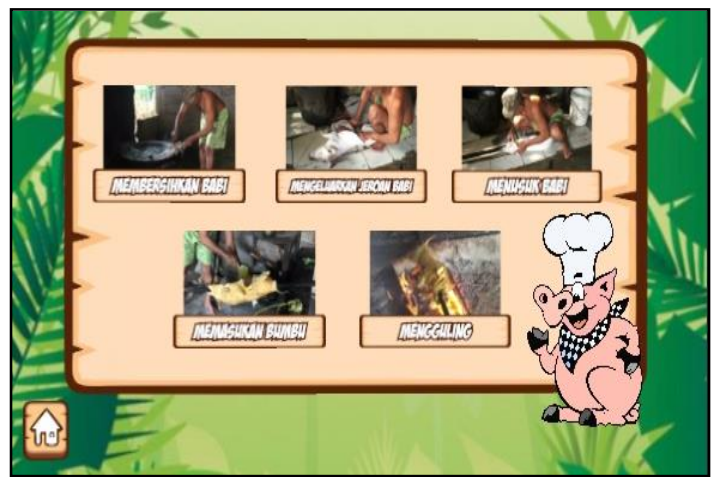

(a)

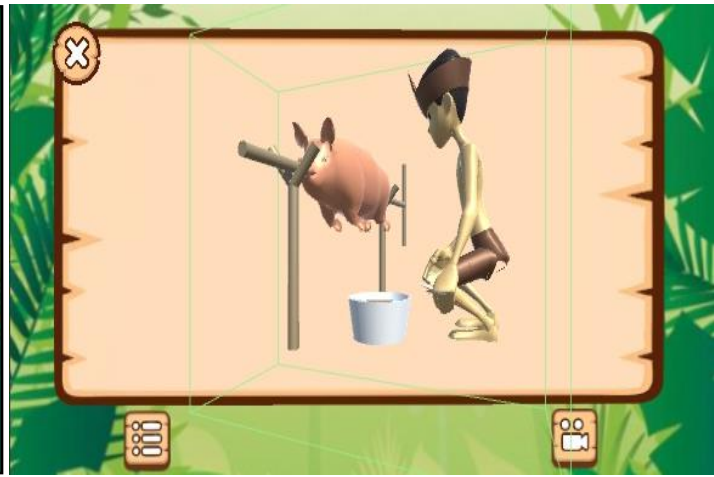

(b)

Gambar 3. Tampilan Menu Animasi: (a) Menu Animasi; (b) Tampilan Animasi 3D

Gambar 3(a) merupakan tampilan dari Menu Animasi yang menampilkan pilihan tentang bagian dari beberapa proses pembuatan babi guling. Gambar 3(b) memperlihatkan bagaimana antar muka animasi 3D dari salah satu proses pengolahan babi guling. Tombol informasi digunakan untuk menampilkan informasi dari penjelasan proses salah satu dari pengolahan babi guling. Tombol video digunakan untuk menampilkan video nyata dari salah satu proses pengolahan babi guling.

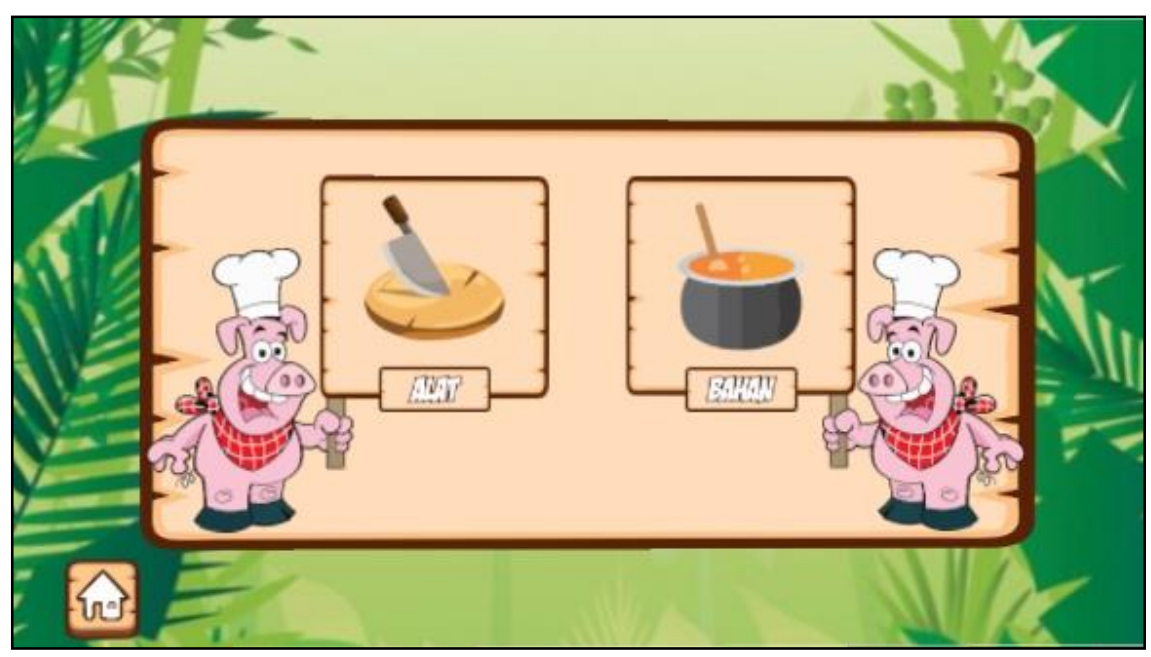

Gambar 4. Tampilan Menu Alat \& Bahan

Gambar 4 Merupakan Tampilan Halaman Menu Alat \& Bahan. Pada Gambar 4 memperlihatkan dua pilihan menu yaitu Alat di sebelah kiri, dan Bahan pada sisi sebelah kanan. Menu pilihan Alat digunakan untuk menampilkan alat-alat yang digunakan pada proses pembuatan babi guling, dan menu pilihan Bahan menampilkan bahan-bahan yang digunakan untuk membuat bumbu pada proses pembuatan babi guling. Tampilan pada Halaman Menu Alat dan Bahan juga memberikan tombol backhome yang berfungsi untuk mempermudah kembali ke halaman Menu Utama. 


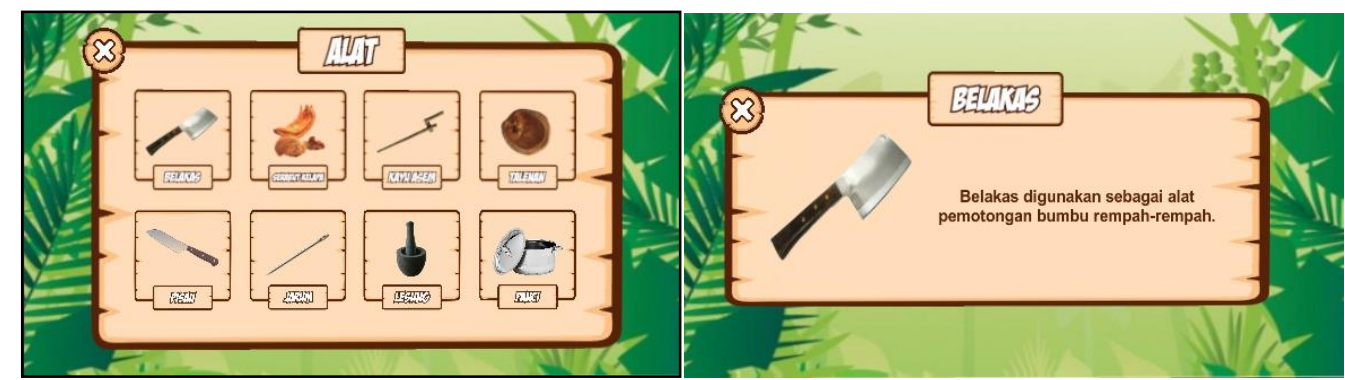

Gambar 5. Tampilan Menu Alat

Gambar 5 memperlihatkan halaman Menu Alat yang menampilkan gambar dan informasi mengenai kegunaan dari alat yang digunakan dalam proses pengolahan babi guling. User dapat memilih gambar alat yang terdapat pada Menu Alat untuk menampilkan gambar serta informasi dari kegunaan alat. Tombol $X$ yang terdapat pada pojok kiri atas informasi Alat digunakan untuk kembali ke Halaman Menu Alat.

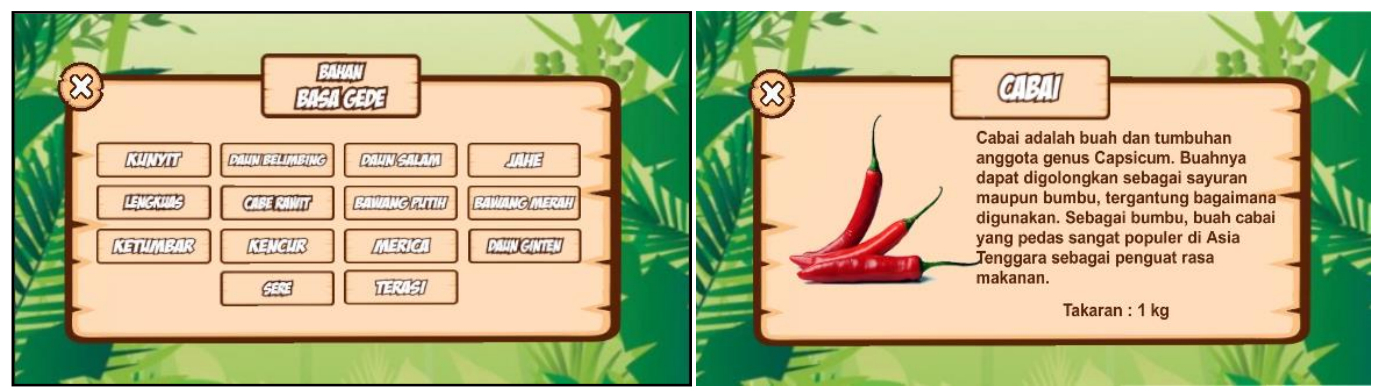

Gambar 6. Tampilan Menu Bahan

Gambar 6 menampilkan halaman Menu Bahan yang terdiri dari gambar dan informasi kegunaan bahan yang digunakan dalam proses pembuatan bumbu serta takaran bahan yang digunakan pada pengolahan babi guling. User dapat memilih bahan pada halaman Menu Bahan untuk menampilkan gambar bahan serta informasi dari bahan yang digunakan. Tombol $\mathrm{X}$ yang terdapat pada pojok kiri atas informasi bahan digunakan untuk kembali ke Halaman Menu Bahan.

\subsection{Hasil Pengujian}

Pengukuran kepuasan pengguna atau user experience pada suatu sistem dapat diukur dalam berbagai metode salah satunya dengan metode pengumpulan data kuesioner. Kuesioner adalah alat yang murah dan sangat efisien untuk mencapai ukuran kuantitatif user experience (UX) suatu sistem. Pengujian dengan kuesioner dilakukan kepada 30 responden yang terdiri dari 25 orang mahasiswa yang menyukai makanan babi guling serta 5 orang pakar yang mengerti tentang proses pembuatan babi guling. Komponen-komponen penyusun kuesioner terdiri dari beberapa pertanyaan-pertanyaan yang tertera pada Tabel 1.

Tabel 1. Penilaian Responden Terhadap Sistem

No.

Pernyataan

1. Aplikasi dapat berjalan baik dan efisien pada perangkat Android.

2. Pengguna merasa nyaman dengan tampilan aplikasi yang menarik.

3. Alur kerja aplikasi yang sederhana dan mudah digunakan.

4. Proses pembuatan babi guling sudah sesuai dengan sebagaimana mestinya.

5. Media pembelajaran lebih mudah dipahami dan meteri yang disajikan lengkap

6. Media pembelajaran menggunakan konsep animasi 3 dimensi meningkatkan minat dan semangat belajar.

7. Mendukung pengguna dalam mempelajari proses pembuatan babi guling.

8. Informasi yang terdapat dalam sistem bermanfaat. 

9. Secara umum sistem sudah sesuai dengan ekspektasi dan kebutuhan pengguna.
10. Aplikasi Proses Pembuatan Babi Guling dengan Onjek 3D Berbasis Android layak untuk dijadikan media pembelajaran terkini dalam mempelajari proses pembuatan babi guling.

Tabel 1 merupakan tabel penilaian responden terhadap sistem guna mengukur seberapa puas responden terhadap sistem. Responden memberikan rentang nilai 1 sampai 5 untuk setiap pertanyaan pada kuesioner. Hasil kuesioner kepuasan pengguna dapat dilihat pada Gambar 7.

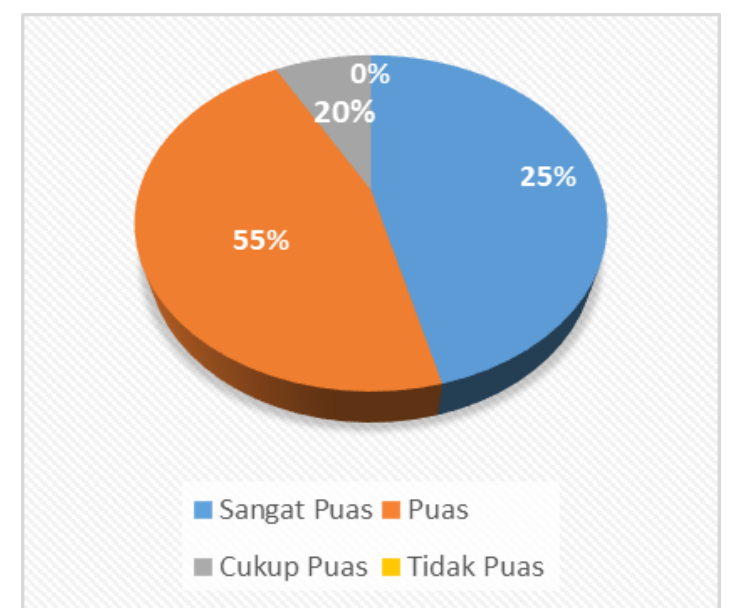

Gambar 7. Tingkat kepuasan pengguna terhadap aplikasi

Gambar 7 merupakan persentase hasil kuesioner tingkat kepuasan pengguna terhadap Aplikasi Pembelajaran Proses Pengolahan Babi Guling dengan Objek 3D Berbasis Android. Hasil yang diperoleh dari 30 orang responden, terdapat $0 \%$ tidak puas, $20 \%$ menyatakan cukup puas, $55 \%$ menyatakan puas, dan $25 \%$ menyatakan sangat puas.

\section{Kesimpulan}

Pemodelan 3 dimensi yang disajikan dalam aplikasi dapat membantu memberikan gambaran bagaimana proses pembuatan babi guling serta dapat memberikan informasi mengenai alat dan bahan yang digunakan dalam proses pembuatan bumbu babi guling. Hasil evaluasi terhadap 30 responden dari 10 pertanyaan yang diajukan yaitu rata-rata $87,6 \%$ kepuasan pengguna terhadap aplikasi. Aplikasi berbasis android menjadikan aplikasi lebih mudah dijangkau serta diakses secara cepat dan real-time. Aplikasi Pembelajaran Proses Pembuatan Babi Guling dengan Objek 3D Berbasis Android diharapkan dapat menjadi media pembelajaran mengenai bagaimana proses pembuatan babi guling dengan objek 3 dimensi melalui fitur dalam aplikasi.

\section{Daftar Pustaka}

[1] I. . Bagiarta, G. . Mudita, R. Rono, and S. . Lindawati, "Peternakan Tropika," e-jurnal FAPET UNUD, vol. 5, no. 1, pp. 181-188, 2017.

[2] G. I. R. Martha, P. A. Bayupati, and I. K. A. Purnawan, "Aplikasi 3D Terrain Virtual Recreation Garuda Wisnu Kencana Cultural Park," J. IIm. Merpati Univ. Udayana, vol. 4, no. 2, pp. 188-194, 2016.

[3] I. N. A. Wijaya, A. A. K. O. Sudana, and P. W. Buana, "Membuat Ketupat Dengan Animasi Model 3D Berbasis Android," Merpati, vol. 4, no. 1, pp. 1-9, 2016.

[4] I. G. Agung, S. Mahadewi, G. Made, A. Sasmita, and K. S. Wibawa, "Aplikasi Animasi 3 Dimensi Mendem Ari-Ari Berbasis Android," J. IIm. Merpati Univ. Udayana, vol. 4, no. 1, pp. 114-122, 2016.

[5] O. Sudan, A. A. K. Sukarsa, and W. Saputra, "Information System of Yadnya Ceremony on Android-Based," Int. J. Hybrid Inf. Technol., vol. 7, no. 6, pp. 155-164, 2015. 
[6] N. P. S. Franza, A. A. K. Oka Sudana, and K. S. Wibawa, "Application of basic Balinese dance using augmented reality on android," J. Theor. Appl. Inf. Technol., vol. 90, no. 1, pp. 61-66, 2016.

[7] I. D. M. Y. A. Putra, A. A. K. A. C. Wiranatha, and P. W. Buana, "Rancang Bangun Game Tapel Bali Pada Platform Android," Lontar Komput., vol. 6, no. 1, pp. 1-12, 2015.

[8] G. S. Prabowo, I. K. A. Purnawan, N. Kadek, and D. Rusjayanthi, "Rancang Bangun Animasi 3D Pembelajaran Shalat Jenazah Berbasis Android," J. IIm. Merpati Univ. Udayana, vol. 4, no. 1, pp. 104-113, 2016.

[9] J. Li and M. Kang, "Using Multimedia to Promote Teaching Effectiveness in the Classroom of China," no. Scict 2014, pp. 242-244, 2014.

[10] C. Bagus, M. Sanjaya, J. Teknologi, I. Universitas, and B. Bali, "Rancang Bangun Aplikasi Game Edukasi Bahasa Bali pada Platform Android," Merpati, vol. 2, no. 1, pp. $1-11,2014$. 